\title{
Comparison of principal component analysis algorithm and local binary pattern for feature extraction on face recognition system
}

\author{
Ichsan Taufik ${ }^{1, *}$, Maya Musthopa $^{1}$, Aldy Rialdy Atmadja ${ }^{1}$, Muhammad Ali Ramdhani $^{1}$, Yana Aditia Gerhana ${ }^{5}$, and Nanang \\ Ismail $^{2}$ \\ ${ }^{1}$ UIN Sunan Gunung Djati Bandung, Informatic Department, Faculty of Science and Technology, Bandung, Indonesia \\ ${ }^{2}$ UIN Sunan Gunung Djati Bandung, Electrical Engineering Department, Faculty of Science and Technology, Bandung, Indonesia
}

\begin{abstract}
Characteristic extraction in face recognition is a step to get characteristic information from the image. The characteristic extraction algorithm is tested against several scenarios of different sunlight and lights, objects facing the camera and not facing the camera. The sample test data were performed on 4 people using a video file or frame numbering 70 for recognizable faces using Principal Component Analysis (PCA) and Local Binary Pattern (LBP) algorithms. The result of the research shows that Local Binary Pattern (LBP) algorithm in object scenario facing camera with sunlighting in room has accuracy of $98.59 \%$, recognition time of 812,817 milliseconds, FAR of $1,41 \%$ and FRR of $0 \%$, while at Principal Component Analysis (PCA) $98.59 \%$ accuracy, recognition time of 1275,761 milliseconds, FAR of $1.41 \%$ and FRR of $0 \%$. Based on these results, the Local Binary Pattern (LBP) algorithm is more efficient than Principal Component Analysis (PCA) for face recognition of the scenarios to be implemented in real-time video.
\end{abstract}

\section{Introduction}

The face recognition system has received a lot of attention in the security field. This system provides user authentication for access control, but when matching the individual identification with the face image on the database is still a problem, this is due to the variability of the human face under different operational conditions e.g. illumination, rotation, expression, camera display, aging and expression [1].

The use of algorithms affect the quality of built systems, then the comparison of characteristic extraction algorithms with local binary pattern algorithm histogram more efficient than eigenface algorithm [2]. However, this study suggests differences in face position while is recognition.

Video is a few frames within which there are objects to be recognized by the face recognition system, as for the type of video used for face recognition that is realtime video [2-5] or video file [6,7]. Real-time video is frame retrieval directly for face recognition, whereas video files are videos stored on a file / file to perform face recognition indirectly.

\section{System Design}

The face recognition system is basically part of an expert system based on image technology. Expert systems are systems that process data in an organized manner [8], which seeks to adapt human knowledge to a computer, so that the computer can solve problems as is usually done by experts [9]. Based on many research results, the expert system has a very good ability in decision making, the system has advantages in terms of: good data accessibility, efficient in time [10], accurate [11], support decisions appropriately [12], more economical [13], broad accessibility [14], improving user understanding [15], improving productivity [16], presenting data and information well [17], and in certain cases can be utilized as data storage media [18].

Face recognition system consists of four stages of face localization using face detection method haar cascade clasiffier, facial normalization is to cut the face image, image size changes and change the image of RGB to grayscale, feature extraction is to get the feature / feature on the face image and matching characteristics the test image with training image to identify the image to be identified identity $[7,19]$. The stages performed in this study are described in sub chapters 2.1 to 2.3 below.

\subsection{Preprocessing}

Preprocessing is an early stage to process input data (face image) before to stage process (face recognition). As for several stages will be explained as follows:

\subsubsection{Face Detection}

The phase of face detection is the phase localization of the face on the frame using the haar cascade classifier algorithm, i.e. the object detection method with a high degree of accuracy and speed [20]. The haar cascade classifier algorithm consists of:

- Create integral image;

* Corresponding author: ichsan@uinsgd.ac.id 
- Adaboost training;

- Cascade Classifier.

\subsubsection{Image Cropping}

At this stage the image is crop from the background of the face image in the frame that is considered unnecessary.

\subsubsection{Image Resizing}

The next process is to change the face image to $128 \mathrm{x}$ 128 pixels, because the initial image resolution is considered too big and will interfere in the next stage.

\subsubsection{Converting RGB Image to Grayscale}

Change the image to grayscale aims to characterize the face is clearly visible and can be taken pattern feature.

\subsection{Feature Extraction}

The process of feature extraction and classification is performed using Principal Component Analysis (PCA) and Local Binary Pattern (LBP) algorithms.

\subsubsection{Principal Component Analysis (PCA)}

Principal Component Analysis is a method of feature extraction and serves to reduce the dimension of image data without losing the information contained in a face image. The following is the preparation of Principal Component Analysis (PCA) algorithm [21]:

a. Setting up data by creating a set of $\mathrm{S}$ consisting of all training images ie $\left(\Gamma_{1}, \Gamma_{2}, \ldots \Gamma_{\mathrm{m}}\right)$

b. Calculation of mean value of an image with equation:

$$
\begin{array}{r}
\mathrm{S}=\left(\Gamma_{1}, \Gamma_{2}, \ldots \Gamma_{\mathrm{m}}\right) \\
\mu=\frac{1}{n} \sum_{i=1}^{n} x_{i}
\end{array}
$$

Information:

$x_{i}=$ data ke $-\mathrm{i}$ from variabel $x$

$\mathrm{n}=$ numbers of data

Calculation of the mean value to reduce the dimension to be calculated in the next process.

c. Finding the value of the image covariant matrix with the following equation:

$$
S=\frac{1}{n} \sum_{i=1}^{n}\left(x_{i}-\mu\right)\left(x_{i}-\mu\right)^{T}
$$

The purpose of this covariate matrix search is to facilitate the search for eigenvalues and eigenvectors.

d. Calculate eigenvalue $\lambda_{i}$ and eigenvector $\boldsymbol{v}_{\boldsymbol{i}}$ from $\mathbf{S}$ (kovariate matrix) with the following equation:

$$
S v_{i}=\lambda_{i} v_{i}, i=1,2, \ldots, n
$$

e. Sorts the eigenvector and eigenvalue values from large to small based on the order of eigenvalues. The main component $k$ is the eigenvector corresponding to the largest eigenvalue.

The main component $k$ of the vector $x$ is observed using the equation:

$$
y=W^{T}(x-\mu)
$$

Where $W=\left(\mathrm{v}_{1}, \mathrm{v}_{2}, \ldots, \mathrm{v}_{\mathrm{k}}\right)$

The Eigenvector in PCA is expressed as a facial characteristic, therefore this method is often referred to as the eigenface method [22].

\subsubsection{Local Binary Pattern (LBP)}

Local Binary Patterns are descriptors that describe localized texture patterns on grayscale images [23]. LBP is defined as a set of circular neighborhoods with centered pixels in the middle as shown in Figure 1 The $g_{i}$ notation is the pixel value of the i-th neighbor. $g_{c}$ is the central pixel used as the threshold value for the pixel to become a binary code.

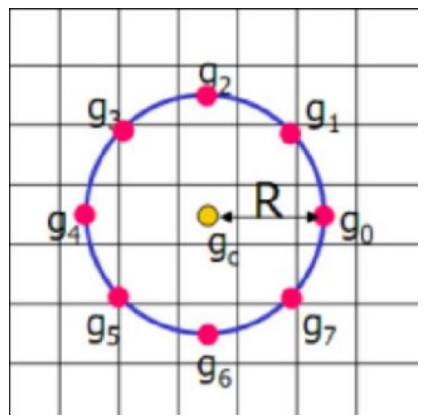

Fig. 1. Circular neighborhood 8 sampling points [23].

Thresholding is done to get the LBP value on neighboring circular pixels using the central pixel, then multiplying by binary weighting. For example for sampling points $\mathrm{P}=8$ and radius $\mathrm{R}=1$, the calculation of LBP values is illustrated in Figure 2.

Binary value $=01001001, \mathrm{LBP}=2+16+128=14$ 




Fig. 2. Calculation value LBP Example [24].

\subsection{Distance Measurement (Classification)}

The classification stage is generally done in two main processes namely training and testing process [25]. The training process is carried out using a set of training data in the form of training images containing the characteristic parameters used to distinguish between one object and another object. Meanwhile, the testing process maps the train data to the target of training through a formula. There are several approaches between them based on statistics (machine learning) or rule-based (rule-based) [26]. In this study researchers using Euclidean Distance algorithm and Chi Square Distance, the explanation as follows:

\subsubsection{Euclidean Distance}

Euclidean Distance is the most commonly used metric for calculating the similarity of two vectors [27] with the following equation:

$$
d_{i j}=\sqrt{\sum_{i=1}^{n}\left(x_{i k}-x_{j k}\right)^{2}}
$$

Explanation:

$d_{i j}=$ disimilary degree

$n=$ number of vectors $x_{i k}=$ vector training image

$x_{j k}=$ vector testing image

\subsubsection{CHI SQUARE DISTANCE}

Chi Square Distance is used to compare the difference of histogram value value from training image in database with histogram value from test image. When comparing two histograms ( $\mathrm{H} 1$ and $\mathrm{H} 2)$ by selecting a matrix (d $\left.\left[\begin{array}{llll}\mathrm{H} & 1 & \mathrm{H} & 2\end{array}\right]\right)$ to assess how well the histogram is, OpenCV implements the compareHist function to perform a comparison [28] with the following equation:

$$
\sum_{i=1}^{n} \frac{\left(x_{i}-y_{i}\right)^{2}}{y_{i}}
$$

\section{Research Methodology}

This research consists of several research related to the research conducted that is system architecture, application architecture and application testing parameter which will be explained as follows [29].

\footnotetext{
* Corresponding author: ichsan@uinsgd.ac.id
} 


\subsection{System Architecture}

System architecture is designed with the aim of knowing how the system when implemented and what components are related to this research, as seen in Figure 3 there are several components that support the running of the system, such as webcam, laptop, software, people objects, etc.

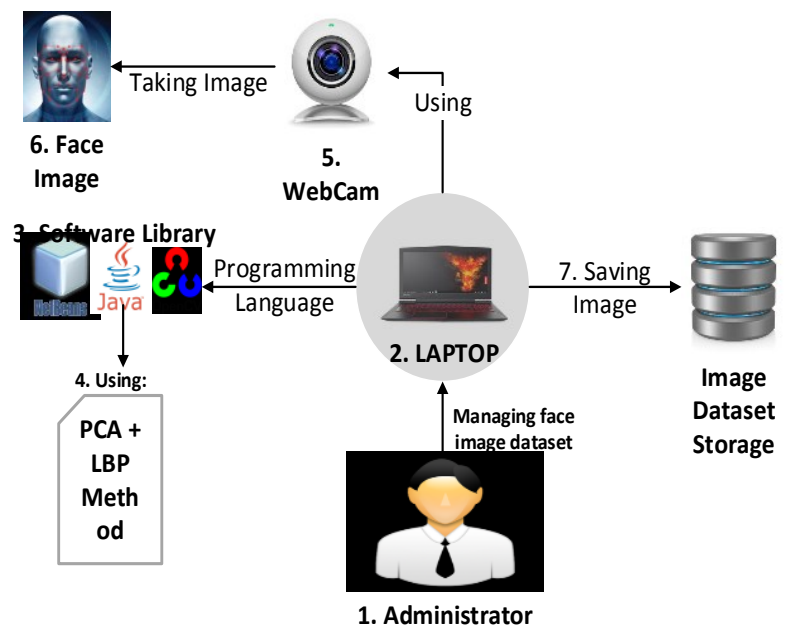

Fig. 3. System Architecture.

The application system is in a java programming that is on a computer with the help of a camera hardware to see objects to be tested with Netbeans software and OpenCV libraries using PCA and LBP methods. Recognized data is then stored on the image dataset.

\subsection{Testing Parameters}

Test parameters are used to calculate the efficiency of the comparable algorithm. The parameters used are described below.

\subsubsection{Accuracy}

Accuracy is a measure of the accuracy of the system in recognizing the input given to produce the correct output.

Accuracy formula $=\frac{\text { number of correct }}{\text { number of datas }} x 100 \%$

\subsubsection{Time of Recognition}

Computational time is the time it takes the system to perform a process using the time calculation completed minus the start time.

1. False Acceptance Rate (FAR)

FAR is the percentage of unauthorized users that are authenticated as legitimate users [2]. FAR on the system is a mistake in recognizing the identity of the input image, either the error in recognizing the input image of the individual outside the detected database as an individual in the database, nor the error in recognizing the input image of the individual in the database identified as another individual [29].

$$
\text { FAR Formula }=\frac{\text { Numbers of Data FAR }}{\text { Numbers of data }} \times 100 \%
$$

2. False Rejection Rate (FRR)

FRR is the percentage of legitimate users denied in authentication [2]. The FRR in this system is an error in rejecting the input image, i.e. an image of the input that should be recognized (the identity contained in the database) becomes unrecognized [30].

$$
\text { FRR Formula }=\frac{\text { Numbers of data } F R R}{\text { Numbers of data }} \times 100 \%
$$

\subsection{Face Dataset}

Face dataset is a collection of data that is divided into two parts namely the training of face images and face image testing, the following explanation about it:

\section{Face Image Training Dataset}

The image training dataset is a collection of image data obtained during the training process. As for the training stage of the facial image as shown in Figure 4.



Fig. 4 Face Image Training Dataset.

2. Face Image Testing Dataset

The image testing dataset is a collection of image data obtained during the test process. As for the training stage of the facial image as shown in Figure 5. 


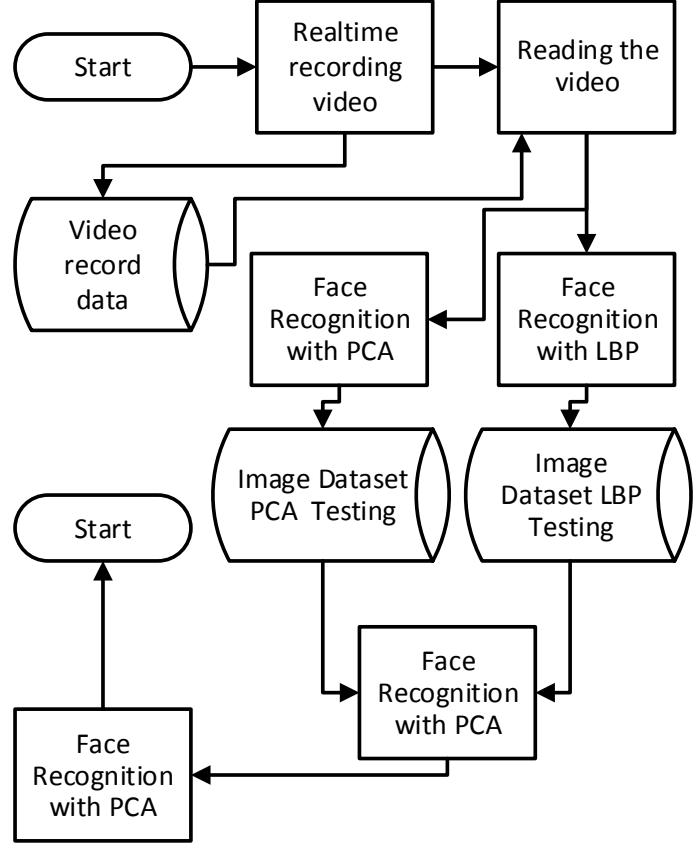

Fig. 5. Face Image Testing Dataset.

The total amount of image data is obtained on the video / collection of training frames and tests with the number of training images 80 and 241 test images, so the total face image is 321 of 360 frames. The following overview of the sequence of image data obtained in Figure 6.

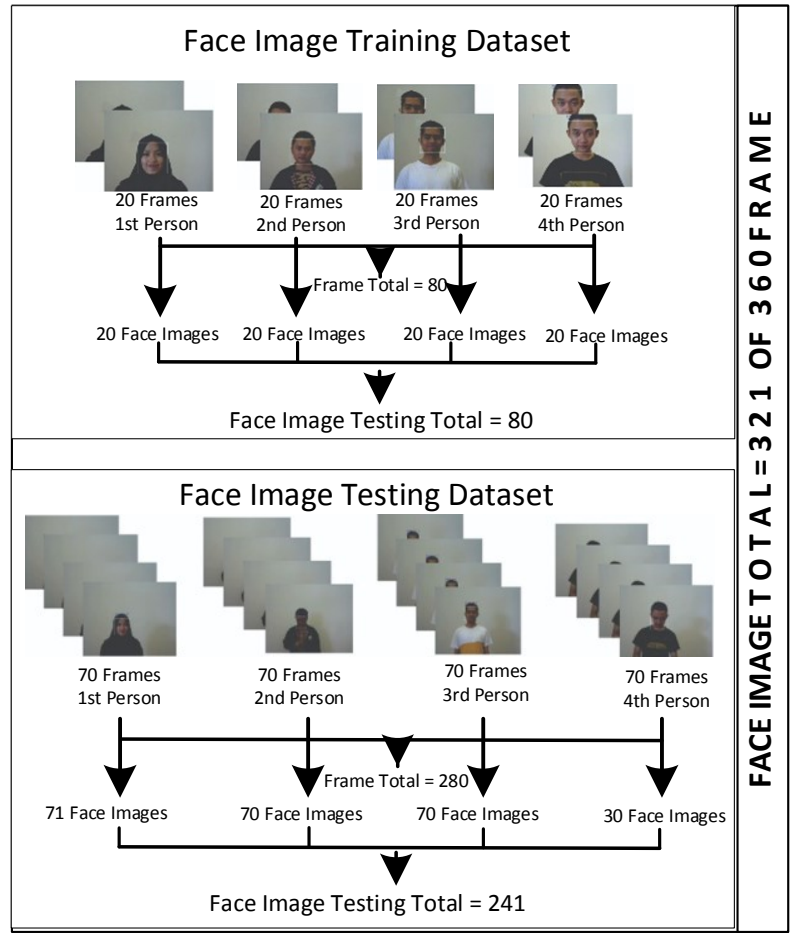

Fig. 6. Stages of obtaining Image Data.

\section{Result}

The test results were performed using a combination of 4 scenarios against Principal Component Analysis (PCA) and Local Binary Pattern (LBP) algorithms. The scenario results in comparison of average accuracy, average recognition time, FAR and FRR PCA and LBP algorithms can be seen in Table 1 and Table 2.

Table 1. Comparison of average accuracy and average recognition time.

\begin{tabular}{|c|c|c|c|c|}
\hline &  & 密 & 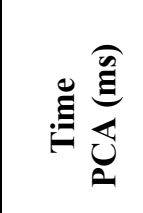 &  \\
\hline $\begin{array}{l}\text { Objects facing } \\
\text { camera + Sunlight } \\
\text { Room }\end{array}$ & 98,59 & 98,59 & 1275,761 & 812,817 \\
\hline $\begin{array}{l}\text { Objects not facing } \\
\text { camera + Sunlight } \\
\text { Room }\end{array}$ & 37,14 & 87,14 & 1466,70 & 842,55 \\
\hline $\begin{array}{l}\text { Objects facing } \\
\text { camera + Light } \\
\text { Room Lamp }\end{array}$ & 75,71 & 98,57 & 1265,629 & 685,071 \\
\hline $\begin{array}{l}\text { Objects not facing } \\
\text { camera + Light } \\
\text { Room Lamp }\end{array}$ & 30 & 37,15 & 1291,20 & 712,90 \\
\hline
\end{tabular}

Table 2. Comparison of FAR and FRR, PCA and LBP.

\begin{tabular}{|l|l|l|l|l|}
\hline \multicolumn{1}{|c|}{} & (n) & & & \\
\hline $\begin{array}{l}\text { Objects facing } \\
\text { camera + } \\
\text { Sunlight Room }\end{array}$ & 1,41 & 1,41 & 0 & 0 \\
\hline $\begin{array}{l}\text { Objects not } \\
\text { facing camera }+ \\
\text { Sunlight Room }\end{array}$ & 62,86 & 12,86 & 0 & 0 \\
\hline $\begin{array}{l}\text { Objects facing } \\
\text { camera + Light } \\
\text { Room Lamp }\end{array}$ & 24,29 & 1,43 & 0 & 0 \\
\hline $\begin{array}{l}\text { Objects not } \\
\text { facing camera }+ \\
\text { Light Room } \\
\text { Lamp }\end{array}$ & 12,86 & 5,71 & 57,14 & 57,14 \\
\hline
\end{tabular}

\section{Conclusion}

The designed system is able to perform face recognition by utilizing OpenCV library. The result of the comparison of characteristic extraction algorithm is obtained by time-efficient algorithm that is Local Binary Pattern. Scenario with efficient results as in Table 2 that is on the condition of the object facing the camera and sunlight in the room that is the average accuracy of $98.59 \%$, the average time of introduction of 812.817 milliseconds. 


\section{References}

1. M. Savvides, J. Heo, and S. W. Park, "Introduction to Face Recognition," in Handbook of Biometrics, A. K. Jain, P. Flynn, and A. A. Ross, Eds. pp. 4445. (USA: Springer, 2008)

2. H. Simaremare and A. Kurniawan, "Perbandingan Akurasi Pengenalan Wajah Menggunakan Metode LBPH dan Eigenface dalam Mengenali Tiga Wajah Sekaligus secara Real-Time," J. Sains, Teknol. dan Ind., vol. 14, no. 1, pp. 66-71, (2016)

3. R. Primartha, "Penerapan Enkripsi dan Dekripsi File menggunakan Algoritma Advanced Encryption Standard (AES)," J. Res. Comput. Sci. Appl., vol. 2, no. 1, pp. 13-18, (2013)

4. L. W. Alexander, S. R. Sentinuwo, A. M. Sambul, T. Informatika, U. Sam, and R. Manado, "Implementasi Algoritma Pengenalan Wajah Untuk Mendeteksi Visual Hacking," E-Journal Tek. Inform., vol. 11, no. 1, (2017)

5. F. A. Hannan, Z. Khalid, and A. Rafiq, "Comparative Analysis of Face Recognition Methodologies and Techniques," NFC-IEFR J. Eng. Sci. Res., vol. 4, no. 1, pp. 37-44, (2016)

6. P. Jaturawat and M. Phankokkruad, "An evaluation of face recognition algorithms and accuracy based on video in unconstrained factors," in Proceedings - 6th IEEE International Conference on Control System, Computing and Engineering, pp. 240-244. (ICCSCE 2016, 2017)

7. D. G. Wahana, D. Dr. Ir.Bambang Hidayat, and M. Suci Aulia ST, "Implementasi Dan Analisis Sistem Pengenalan Wajah Dalam Ruangan Pada Video Menggunakan Metode LNMF DAN NMFsc," eProceeding Eng., vol. 2, no. 1, pp. 389-395, (2015)

8. D. S. Maylawati, W. Darmalaksana, and M. A. Ramdhani, "Systematic Design of Expert System Using Unified Modelling Language," IOP Conf. Ser. Mater. Sci. Eng., vol. 288, no. 1, p. 12047, (2018)

9. M. A. Ramdhani, Metodologi Penelitian untuk Riset Teknologi Informasi. Bandung: UIN Sunan Gunung Djati Bandung, (2013)

10. C. Slamet, A. Rahman, A. Sutedi, W. Darmalaksana, M. A. Ramdhani, and D. S. Maylawati, "Social Media-Based Identifier for Natural Disaster," IOP Conf. Ser. Mater. Sci. Eng., vol. 288, no. 1, p. 12039, (2018)

11. C. Slamet, R. Andrian, D. S. Maylawati, W. Darmalaksana, and M. A. Ramdhani, "Web Scraping and Naïve Bayes Classification for Job Search Engine," vol. 288, no. 1, pp. 1-7, (2018)

12. Y. A. Gerhana, W. B. Zulfikar, A. H. Ramdani, and M. A. Ramdhani, "Implementation of Nearest Neighbor using HSV to Identify Skin Disease," IOP Conf. Ser. Mater. Sci. Eng., vol. 288, no. 1, p. 0121531234567890 Implementation, (2018)

13. A. Rahman, C. Slamet, W. Darmalaksana, Y. A. Gerhana, and M. A. Ramdhani, "Expert System for Deciding a Solution of Mechanical Failure in a Car using Case-based Reasoning," IOP Conf. Ser. Mater. Sci. Eng., vol. 288, no. 1, p. 12011, (2018)
14. C. Slamet, A. Rahman, M. A. Ramdhani, and W. Darmalaksana, "Clustering the Verses of the Holy Qur'an Using K-Means Algorithm," Asian J. Inf. Technol., vol. 15, no. 24, pp. 5159-5162, (2016)

15. D. S. Maylawati, M. A. Ramdhani, W. B. Zulfikar, I. Taufik, and W. Darmalaksana, "Expert system for predicting the early pregnancy with disorders using artificial neural network," 2017 5th Int. Conf. Cyber IT Serv. Manag. CITSM 2017, (2017)

16. W. B. Zulfikar, Jumadi, P. K. Prasetyo, and M. A. Ramdhani, "Implementation of Mamdani Fuzzy Method in Employee Promotion System," IOP Conf. Ser. Mater. Sci. Eng., vol. 288, no. 1, p. 12147, (2018)

17. D. S. Maylawati, M. A. Ramdhani, A. Rahman, and W. Darmalaksana, "Incremental technique with set of frequent word item sets for mining large Indonesian text data," 2017 5th Int. Conf. Cyber IT Serv. Manag. CITSM 2017, pp. 1-6, (2017)

18. A. Taofik, N. Ismail, Y. A. Gerhana, K. Komarujaman, and M. A. Ramdhani, "Design of Smart System to Detect Ripeness of Tomato and Chili with New Approach in Data Acquisition," in IOP Conference Series: Materials Science and Engineering, 2018, vol. 288, no. 1, p. 1 (2018)

19. F. Brilian, A. Fatchul Huda, I. Taufik, " Sistem Pengenalan Wajah Dengan Menggunakan Metode Linear Discriminant Analysis (LDA)," Konferensi Nasional Sistem Informasi, 2355-1941, (2014)

20. N. Syafitri and Adri, "Prototype Pendeteksi Jumlah Orang Dalam Ruangan," IT J. Res. Dev., vol. 1, no. 2, pp. 40-43, (2017)

21. T. D. OpenCV, "Face Recognition with OpenCV," OpenCV 2.4.13.0 documentation, (2016)

22. J. Rekursif, A. R. Syakhala, D. Puspitaningrum, and E. P. Purwandari, "Perbandingan Metode Principal Component Analysis ( PCA ) Dengan Metode Hidden Markov Model ( HMM ) Dalam Pengenalan Identitas," vol. 3, no. 2, pp. 70-71, (2015)

23. I. Kusmana, "Penggabungan Fitur Local Binary Patterns Untuk Identifikasi Citra Tumbuhan Obat," Inst. Teknol. Bogor, p. 2, (2011)

24. T. Lindahl, "Study of Local Binary Patterns," Sci. Technol., p. 3, (2007)

25. A. Pamungkas, "Pengenalan Pola Pemrograman Matlab," (2017)

26. T. Ridwan and M. I. NS, "Kalkulator Visual Pada Tulisan Tangan Memanfaatkan Pengenalan Pola Berbasis Aturan Dengan Levenshtein Distance untuk Menghasilkan Informasi Ucapan," JOIN (Jurnal Online Inform., vol. 1, no. 2, pp. 107-110, (2016)

27. S. R. Wurdianarto, "Perbandingan Euclidean Distance Dengan Canberra Distance Pada Face Recognition," Techo.COM, vol. 13, no. 1, pp. 34$35,(2014)$

28. OpenCV, "Histograms - OpenCV 2," docs.opencv.org, (2016)

29. D. Putra, "Perbandingan Biometrika," in Sistem Biometrika, C. W. Hermawan, Ed. pp. 30-33. (Yogyakarta: ANDI, 2009) 
30. S. Rahmawati, I. Taufik, and G. Sandi, “(Advanced Encryption Standard) 256 bit dan Kompresi Menggunakan Algoritma Huffman Pada," pp. 1-9, (2017) 